\title{
Prevalence of Occult Hepatitis C Virus Infection among Blood Donors in Jiangsu, China
}

\author{
Hong Lin ${ }^{a} \quad$ Xian Chen ${ }^{a}$ Shaowen Zhu ${ }^{a}$ Ping Mao ${ }^{a}$ Shanshan Zhu ${ }^{a}$ \\ Yanchun Liu ${ }^{a}$ Chengyin Huang ${ }^{a}$ Jun Sun ${ }^{a}$ Jin Zhu ${ }^{b}$ \\ a Jiangsu Province Blood Center and ${ }^{b}$ Huadong Medical Institute of Biotechniques, Nanjing, China
}

\section{Keywords}

Hepatitis $C$ virus · Occult infection · Peripheral blood mononuclear cells $\cdot$ Blood donors

\begin{abstract}
Objective: In 2010, only 1 donor blood sample was found to be anti-hepatitis $\mathrm{C}$ virus (HCV) negative and HCV RNA positive, as detected by nucleic acid testing. In occult HCV infection $(\mathrm{OCl}), \mathrm{HCV}$ RNA is found in peripheral blood mononuclear cells (PBMCs). We investigated the prevalence of $\mathrm{OCl}$ among blood donors. Methods: We collected 513 samples from 334 eligible and 179 deferred donors, including 55 antiHCV-positive, 113 alanine aminotransferase (ALT)-elevated, and 11 hepatitis $B$ virus surface antigen ( $\mathrm{HBsAg}$ )-positive blood donors. PBMCs were isolated, the $5^{\prime}$-untranslated region of HCV RNA was amplified by reverse transcription nested PCR, and the genotype of the core region was determined. Results: No HCV RNA was detected among the eligible samples. Among the deferred donors, 15 (27.2\%) had detectable HCV RNA in 55 anti-HCV PBMC specimens. HCV RNA was detected in 1 (9.1\%) HBsAg-positive and 9 (8\%) ALTelevated samples. The prevalence of $\mathrm{OCl}$ in the blood donors was $2.2 \%$ (10/458). HCV genotypes were determined in 10 subjects, indicating that 2 (20.0\%) were subtype $2 a, 7(70.0 \%)$
\end{abstract}

\section{KARGER}

E-Mail karger@karger.com

www.karger.com/int were $1 \mathrm{~b}$, and 1 (10\%) was $6 \mathrm{a}$. Conclusions: This study showed that $\mathrm{OCl}$ does exist among Chinese blood donors. However, to determine the epidemiology and outcome of this HCV infection, further follow-up with more participants and patients receiving blood components with $\mathrm{OCl}$ is needed.

ㄷ) 2017 S. Karger AG, Basel

\section{Introduction}

Hepatitis $\mathrm{C}$ virus (HCV) is one of the most common viral infections of the liver. Each year, 3-4 million people worldwide are infected with $\mathrm{HCV}$, with approximately 150 million being chronically infected and more than 350,000 people dying each year from HCV-related liver diseases [1]. A 1992 Chinese national survey showed that the HCV infection rate was $3.2 \%$ in the general population [2]. However, after the implementation of mandatory HCV screenings in 1993 for blood transfusion and other precautions to prevent blood-borne diseases, new

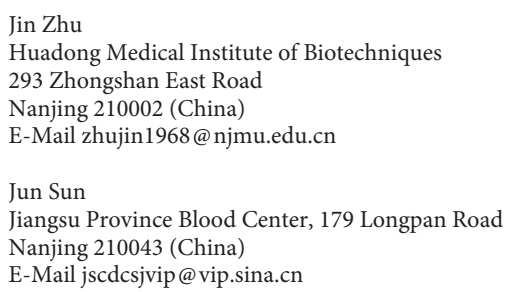


cases of HCV infection associated with blood or blood products have become very rare. Although the anti-HCV prevalence would be much higher in high-risk groups, a survey conducted in 2006 showed that it was only $0.43 \%$ in the general population [3]. However, in recent years the incidence of reported HCV cases has increased [4].

According to a meta-analysis [5], the pooled prevalence of HCV infection among all blood donors in mainland China from 1990 to 2010 was $8.68 \%$. The anti-HCV prevalence in paid blood donors was significantly higher than that in voluntary blood donors $(<1 \%)$. In June 2010 at the Jiangsu Province Blood Center, nucleic acid testing (NAT) was performed as a pilot trial and became a routine screening program in July 2012. Between 2011 and 2012 , the rate of anti-HCV reactivity was $0.25 \%$ (327/ $129,328)$ and that of HCV RNA was $0.10 \%(130 / 129,328)$. Only 1 HCV RNA-positive sample was detected in HBV-, HCV-, HIV- and syphilis seromarker-negative samples. NAT appeared not to have the expected effective role in the screening of HCV infection [6].

Occult HCV infection (OCI) was first reported by Pham et al. [7] in anti-HCV-positive patients who recovered after a self-limited (untreated) episode of hepatitis C infection and in individuals with a sustained virological response due to interferon treatment who had normal liver enzyme levels. OCI is characterized by the presence of genomic HCV RNA strands in liver biopsy and/or peripheral blood mononuclear cell (PBMC) specimens with the absence or undetectable levels of HCV RNA and the absence or presence of anti-HCV antibodies in the plasma by current laboratory methods [8-10]. This occult infection has been reported in individuals with or without chronic liver disease with unknown aetiology in several at-risk groups for HCV infection and also in the general population without any evidence of liver disease $[11,12]$. This study was designed to investigate the OCI prevalence among blood donors and to compare the prevalence of OCI among HCV-positive and HCV-negative blood donors, hepatitis B virus surface antigen (HBsAg)-positive blood donors, and alanine aminotransferase (ALT)elevated ( $>40 \mathrm{IU} / \mathrm{L})$ blood donors.

\section{Materials and Methods}

\section{Study Population}

The present study was performed using a total of 513 voluntary blood donors (391 men and 122 women). All subjects were within the age range of $18-55$ years and were liver disease free at recruitment (Table 1). The donor blood samples were randomly collected at the Jiangsu Province Blood Center between April and December
2012. The study was approved by Ethical Committee of Jiangsu Province Blood Center, and all participants signed an informed consent form when they completed the questionnaire.

\section{Pre-Donation}

Due to the high prevalence of HBV and HCV in China's general population, and to exclude the potential window period of infection, all blood donors were required to pass a routine, predonation screening process, which included a health history questionnaire, pre-donation rapid testing, and a brief physical examination. The health history questionnaire contained the required screening mandated by the Chinese Ministry of Health. Pre-donation rapid testing investigated the presence of $\mathrm{HBsAg}$, determined the ABO blood type, and assessed haemoglobin levels. ALT screening, which indicates liver damage or disease, has also been performed since 2009. Donors were deferred if risk behaviour was detected in the health history questionnaire, if pre-donation rapid testing yielded an abnormal result, or if donors failed the physical examination (e.g., body weight $<45 \mathrm{~kg}$ ). Donors who fulfilled the eligibility requirements completed a consent form permitting their blood sample to be used in research and donation.

\section{Sample Routing Screening at the Blood Centre}

At the blood centre, all donor samples underwent 2 rounds of ELISA testing using 2 different reagents for ALT, anti-HIV-1 and 2, anti-HCV, HBsAg, and syphilis antibodies. HCV ELISA test kits were obtained from Wantai Biological Pharmacy Enterprise Co. Ltd., and Xiamen InTec Products Inc.

\section{Nucleic Acid Testing}

Donor plasma with ELISA-negative samples in the 6-pool were tested for HBV, HCV, and HIV-1 nucleic acids using a Roche Cobas AmpliScreen Cobas S 201 system (F. Hoffmann La Roche Ltd., Basel, Switzerland), and reactive samples were individually detected by a Kehua real-time PCR assay (Shanghai, China) or Roche real-time PCR assay.

\section{Isolation of PBMCs}

PBMCs were prepared using the standard Ficoll ${ }^{\circledR}$ Hypaque centrifugation protocols, which included phosphate-buffered saline (PBS) rinsing stages prior to cryopreservation in $10 \%$ dimethyl sulphoxide. In a $500-\mu \mathrm{L}$ volume of a PBMC solution, $10^{6}$ to $10^{7}$ cells were washed 3 times in PBS to remove any contaminants in the plasma and were stored at $-80^{\circ} \mathrm{C}$.

\section{HCV RNA Extraction and Detection}

Cryopreserved $\mathrm{PBMCs}$ were later thawed at $37^{\circ} \mathrm{C}$ and again rinsed twice with PBS. Total RNA was isolated from $500 \mu \mathrm{L}$ of PBMCs using a High Pure Viral RNA Kit (Roche) following the manufacturer's instructions. Fifty microliters of RNA were eluted. Detection of HCV RNA was performed by RT nested PCR using primers that targeted the $5^{\prime}$-untranslated region $\left(5^{\prime}\right.$-UTR) of the HCV genome [13]: first PCR, F1: 5'-CTGTGAGGAACTACTGTCT-3' (55-73 bp), R1: 5'-GTGCACGGTCTACGAGACCT-3' (321-301 bp); second PCR, F2: 5'GAAAGCGTCTAGCCATGGCGT-3' (119-139), R2: 5'CCCTATCAGGCAGTACCACAA-3' (281-261 bp). Five microliters of extracted RNA were subjected to a single-step reverse transcription $\left(30 \mathrm{~min}\right.$ at $\left.42^{\circ} \mathrm{C}\right)$ and amplified as follows: $5 \mathrm{~min}$ at $95^{\circ} \mathrm{C} ; 25 \mathrm{~s}$ at $94^{\circ} \mathrm{C}, 20 \mathrm{~s}$ at $50^{\circ} \mathrm{C}, 40 \mathrm{~s}$ at $72^{\circ} \mathrm{C}$ for 35 cycles, and a final extension of $5 \mathrm{~min}$ at $72^{\circ} \mathrm{C}$. Three micro- 
Table 1. HCV RNA detection in PBMCs of 4 series of blood donors

\begin{tabular}{|c|c|c|c|c|}
\hline Subjects & Subjects, $n$ & $\begin{array}{l}\text { HCV antibodies, } \\
n(\%)\end{array}$ & $\begin{array}{l}\text { HCV RNA in } \\
\text { plasma, } n(\%)\end{array}$ & $\begin{array}{l}\text { HCV RNA in } \\
\text { PBMCs, } n(\%)\end{array}$ \\
\hline \multicolumn{5}{|l|}{ All series } \\
\hline All subjects & 513 & $55(5.4)$ & $10(2)$ & $25(4.9)$ \\
\hline Men (age range $18-55$ years) & 391 & $38(9.7)$ & $5(1.3)$ & $15(3.8)$ \\
\hline Women (age range $18-50$ years) & 122 & $25(2.1)$ & $5(4.1)$ & $10(8.2)$ \\
\hline \multicolumn{5}{|l|}{ Eligible series } \\
\hline All subjects & 334 & 0 & 0 & 0 \\
\hline Men (age range $19-55$ years) & 237 & 0 & 0 & 0 \\
\hline Women (age range $18-50$ years) & 97 & 0 & 0 & 0 \\
\hline \multicolumn{5}{|l|}{$\mathrm{HCV}$ series } \\
\hline All subjects & 55 & $55(100)$ & $10(18.2)$ & $15(27.3)$ \\
\hline Men (age range $18-50$ years) & 38 & $38(100)$ & $5(13.2)$ & $8(21.1)$ \\
\hline Women (age range $18-48$ years) & 17 & $17(100)$ & $5(29.4)$ & $7(41.2)$ \\
\hline \multicolumn{5}{|l|}{ ALT series $(40.6 \sim 159 \mathrm{U} / \mathrm{L})$} \\
\hline All subjects & 113 & 0 & 0 & $9(8.0)$ \\
\hline Men (age range $18-49$ years) & 106 & 0 & 0 & $6(5.7)$ \\
\hline Women (age range $18-27$ years) & 7 & 0 & 0 & $3(42.9)$ \\
\hline \multicolumn{5}{|l|}{ HBsAg series } \\
\hline All subjects & 11 & 0 & 0 & $1(9.1)$ \\
\hline Men (age range 19-52 years) & 10 & 0 & 0 & $1(10.0)$ \\
\hline Women (age range $20-31$ years) & 1 & 0 & 0 & 0 \\
\hline
\end{tabular}

liters of the RT-PCR reaction were added to the second (nested) PCR step and amplified for the other 35 cycles using the same cycling conditions as the first step. The presence of a 162-bp amplification fragment indicated HCV RNA positivity in the sample. HCV RNA-positive $\left(10^{6}\right.$ copies $\left./ \mathrm{mL}\right)$ samples from a chronic HCV patient, HCV marker-negative plasma from blood donors, and RNAfree water were included as positive, negative, and blank controls in each PCR run. All positive samples were analysed twice for confirmation in different runs of PCR amplification to identify contaminated samples. To determine the sensitivity of the nested PCR developed in this study, we performed the PCR using 10-fold serially diluted template RNA extracted from a control with a concentration of $10^{3} \mathrm{IU} / \mathrm{mL}$. The sensitivity was $126 \mathrm{IU} / \mathrm{mL}$ HCV RNA.

\section{HCV Genotype}

The core/E2 region of HCV RNA from the 5 '-UTR PCR-positive samples was amplified by RT-PCR for determination of the HCV genotype. The following primers were used for amplification: first PCR-461 bp, core/F1: 5' -AGGCCTTGTGGTACTGCCTGATA-3', core/R1: 5' -GTATGTACCCCATGAGGTCGGC-3'; second PCR385 bp, F2: 5' -CGGGAGGTCTCGTAGACCGT-3', R2: 5' -AGGGTATCGATGACCTTACCCA- $3^{\prime}$. The amplicons were purified and sequenced directly. The sequence information was analysed by Mega 6.0 software. The sequences obtained from our studied samples were aligned and genotyped together with the reference sequences using the ClustalW alignment program. Reference sequences for the different genotypes of HCV were obtained from GenBank with the accession numbers displayed in Figure 1. Phylogenetic analyses were performed by the Neighbour-Joining method of the Kimura-2-parameter model with 1,000 bootstrap replicates.

\section{Results}

\section{Study Population}

Between April and December 2012, routine screening of nearly 70,000 blood donors tested a total of $236 \mathrm{HBsAg}$ reactions, 94 anti-HCV reactions, and 113 ALT-elevated samples. A total of 513 donors were collected aperiodically in this study, including 55 anti-HCV reaction samples (HCV series), 113 ALT >40 IU/L samples (ALT series), and $11 \mathrm{HBsAg}$ reaction samples (HBsAg series). In the study, 334 eligible blood donors showed normal ALT levels ( $<40 \mathrm{IU} / \mathrm{L})$, and negative results for routine screening served as controls.

\section{HCV RNA in PBMCs}

No HCV RNA was detected in the PBMCs from eligible blood donors. A total of 25 (14\%) of the 179 subjects who were HCV positive, HBsAg positive, and ALT abnormal were positive for HCV RNA. HCV RNA was detected in the plasma of 10 of the 55 (18.2\%) subjects in the HCV antibody series and in the PBMCs of 15 of the 55 (27\%) subjects. On the other hand, $9(8 \%)$ of the 113 subjects in the ALT-abnormal series and 1 (9.1\%) of the 11 subjects in the HBsAg-positive series were positive for HCV RNA in their PBMCs. The prevalence of OCI in the blood donors was 2.2\% (10/458). All of the results are shown in Table 1. 
Fig. 1. Phylogenetic analysis of the HCV core region in OCI samples. Black triangles $(\boldsymbol{\Delta})$ represent OCI samples, others were all reference sequences from GenBank. "A" represents ALT-elevated samples and " $C$ " indicates an anti-HCV-reactive sample.

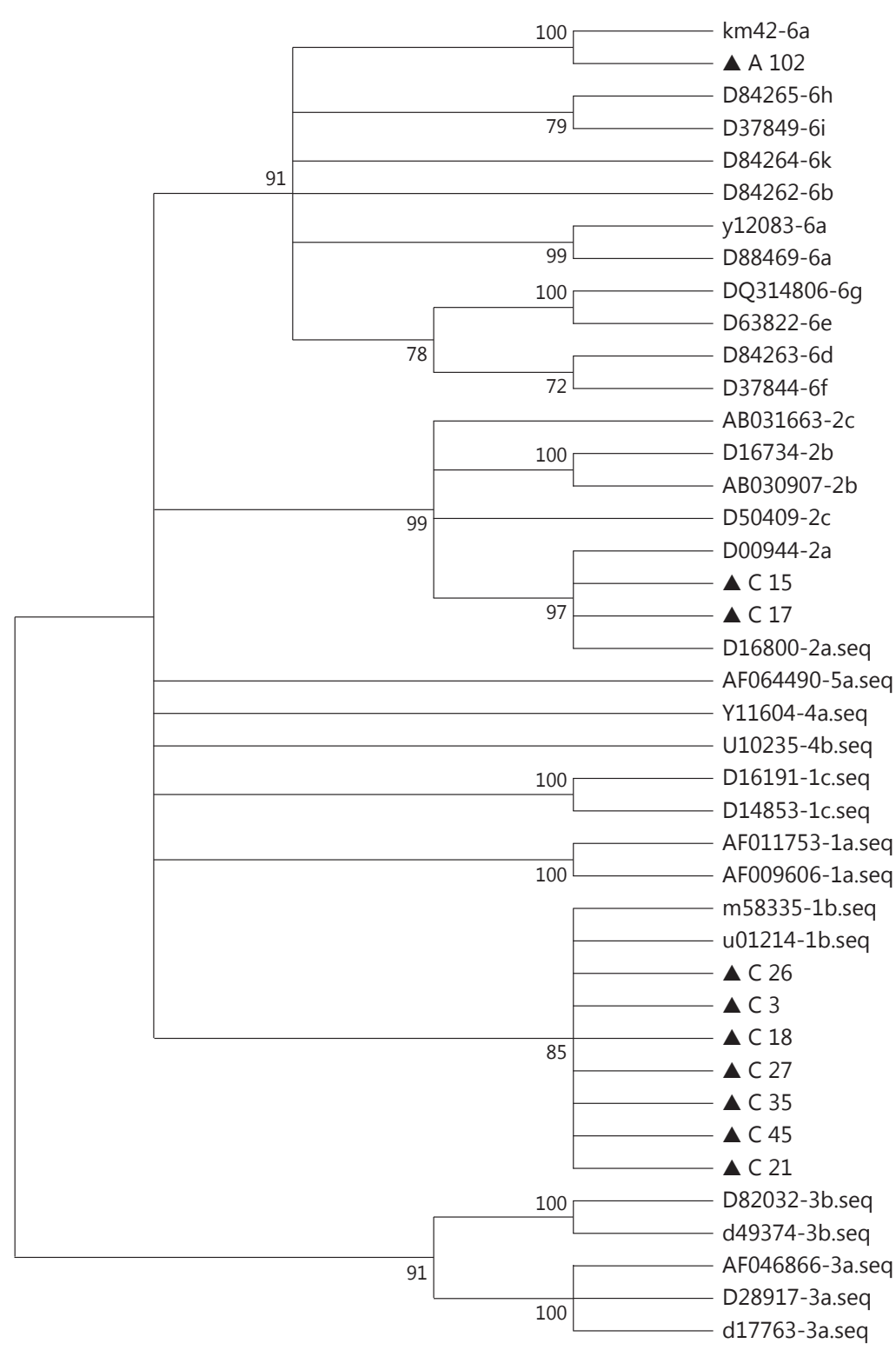

\section{HCV Genotyping}

The 5'-UTR of HCV RNA-positive samples was confirmed by amplification of the core region, and 10 of the 25 specimens were sequenced successfully, resulting in the identification of genotypes $1 \mathrm{~b}$ and $2 \mathrm{a}$ (Fig. 1). Genotype $1 \mathrm{~b}$ was observed in 7 blood donors, genotype $2 \mathrm{a}$ in 2 blood donors, and genotype 6a in 1 blood donor. Other samples were not genotyped due to a weakly detectable PCR fragment.

Occult HCV Infection among Blood Donors

\section{Discussion}

Previous reports have demonstrated that HCV infections in China are very high, but a nationwide HCV serological survey performed in 2006 that used a study population of more than 80,000 Chinese subjects showed that the prevalence of anti-HCV antibodies was $<0.5 \%$ [14]. When NAT was performed in some blood centres, HCV RNA-positive blood donors did not exceed the expected 
levels in ELISA-negative blood donors [6]. The potential risk for HCV to spread from OCI subjects through blood transfusions [15] and haemodialysis units should thus be considered $[16,17]$. It should be considered that current screening strategies most likely overlook blood donors who carry HCV in their PBMCs [18].

$\mathrm{OCI}$ is a new, controversial entity of HCV infection. Little is known about the prevalence of OCI, including its natural history, potential transmission risk, and impact on the general population. In chronic HCV patients following a sustained virological response $[19,20], \mathrm{HCV}$ RNA can be detected in serum; thus, this condition may result in a reservoir of clinical OCI in individuals who donate blood [12]. To determine whether or not a blood donor in China has an OCI, we investigated the HCV RNA in his or her PBMCs. Here, HCV RNA was not detected in the PBMCs among 334 eligible donors. In the $\mathrm{HCV}$ antibody-positive series, HCV RNA in the plasma was detected by NAT using a triplex assay (HIV, HBV, and HCV). The rate was $18.2 \%(10 / 55)$. The prevalence $(27.3 \%, 15 / 55)$ of HCV RNA detectable in PBMCs was more than that observed in plasma samples $(10 \%, 10 / 55)$. This kind of HCV infection is termed secondary OCI, which occurs in anti-HCV antibody-reactive individuals with normal liver function tests [21].

$\mathrm{HBV} / \mathrm{HCV}$ co-infection is not uncommon and is frequently found in HBV-endemic areas, such as Asia, subSaharan Africa, and South America. In several countries, $\mathrm{HBV} / \mathrm{HCV}$ co-infections are observed in $0.9-5 \%$ of patients, but may exceed $25 \%$ in some areas [22]. Between 2007 and 2013, there were only $17 \mathrm{HBV}$ and HCV coinfection blood donors detected by routine screening in our blood centre. In this experiment, HCV RNA was detected in 1 out of $11 \mathrm{HBV}$ infection blood donors, making the percentage $(9.1 \%)$ very high. The number of HBsAgpositive blood donors that were tested for HCV RNA was too low to illustrate the impact in the current assay; however, it did demonstrate that co-infection of HCV and $\mathrm{HBV}$ in blood donors may be more than previously thought.

Cryptogenic OCI is another kind of OCI found in cryptogenic liver disease patients [23] with the absence of anti-HCV. In this investigation, the prevalence of OCI was $8 \%$ in elevated ALT blood donors without other transfusion transmitted infection (TTI) markers. Before the discovery of HCV, ALT was used as a surrogate marker for hepatitis. In 1999, ALT screening was discontinued in the USA when NAT for HCV RNA was introduced. ALT screening in blood donors has also been disputed in China because it deferred about $1-2 \%$ of all blood donors.
In 2013, the ALT screening standard was changed from 40 to $50 \mathrm{IU} / \mathrm{L}$ in order to decrease the number of deferred blood donors; however, it still deferred more than $0.5 \%$ of blood donors. Despite this, from October 2010 to the present, only $1 \mathrm{HCV}$ RNA-positive sample was found in seronegative samples, and no RNA was detected in ALTelevated blood samples. In Brazil, 2 independent studies were presented with conflicting conclusions. Mangus et al. [24] monitored 166 volunteer blood donors with elevated ALT and found that the ALT levels were not useful in detecting donors infected with HCV during blood donation. Gonçales et al. [25] monitored 359 HBsAg- and anti-HCV-negative blood donors with elevated ALT levels. They suggested that ALT can be a useful marker for the detection of $\mathrm{HCV}$-infected donors in whom technical problems may have occurred during serological screening. Furuta et al. [26] collected disqualified donors' plasma with ALT levels of $>60 \mathrm{IU} / \mathrm{L}$, even if they were serologically negative for TTIs, to assess the potential risk of TTIs by metagenomic analysis of virome profiles. The typical TTIs were all negative, suggesting that serum ALT testing may be unsuitable for monitoring the additional risks of TTIs in blood donors who are negative for typical TTIs using serologic tests and NATs. Therefore, the question of how to deal with ALT-elevated samples and donors remains unanswered.

Traditionally, HCV detected in serum or plasma is clinical therapy evidence, but as more and more OCI issues are being discussed, the concern of clinical relevance and influence on the patients has become of great importance [27]. In a follow-up study of people undergoing phlebotomy therapy [28], 6 subjects with OCI were monitored, with only 2 showing detectable HCV infection in PBMCs at 11 and 13 months of follow-up, demonstrating a persistent infection. In the other 4 subjects, none were found to be HCV RNA positive using their PBMCs, even after mitogen stimulation, which demonstrated certain clearance. It is uncertain whether OCI is a different clinical entity or just a form of chronic HCV infection. Chen et al. [29] detected HCV RNA in 24 patients with spontaneous resolution of hepatitis $\mathrm{C}$ who were followed up for $0.3-14.4$ years. The RNA was extracted from plasma and, if HCV negative, from ultracentrifugation and ex vivo stimulated PBMCs. A total of 17 of 24 (70.8\%) individuals carried HCV RNA. This indicated that OCI would persist long after the spontaneous resolution of hepatitis $\mathrm{C}$ at levels undetectable by current testing. In a more recent investigation [30], 2.1\% $(42 / 2,007)$ of blood donations displayed reactivity in a novel $\mathrm{HCV}$-core specific antibody assay. In core reactive samples, 6 blood 
donors had HCV RNA in their PBMCs, serum, and plasma by ultracentrifugation, and 3 had HCV RNA in their serum and plasma. The results reiterated the notion that OCI is perhaps not negligible and infection risk by transfusion should be a concern. In our study, the presence of HCV RNA in blood donors was proven; however, since there was no follow-up, we could not determine whether this infection was persistent or transient. Further careful, longitudinal follow-up of OCI blood donors, especially of female subjects at 12 -month intervals, should be investigated to elucidate whether periodical recurrences of $\mathrm{HCV}$ infection with low viral loads occur in PBMCs. The clinical relevance and the influence of blood safety should be evaluated. There is a need for more countries to participate in order to determine the epidemiology of this type of HCV infection. Additionally, evaluating OCI in blood transfusion centres and in patients who receive large volumes of blood components, such as patients with haemophilia, should be performed in future projects [31].

\section{Acknowledgements}

We gratefully acknowledge funding for our research from Jiangsu Province Department of Health (project grant H201225), Jiangsu Province Department of Science and Technology (natural science funds, BK20131440) and the Jiangsu Province Talent Peak in Six Industries Program (WSN2014002). We would also like to express our gratitude to other colleagues in the clinical laboratory for routine screenings of the specimens.

\section{Disclosure Statement}

The authors declare no conflict of interests.

\section{References}

1 World Health Organisation: Hepatitis C fact sheet. http://www.who.int/mediacentre/factsheets/fs164/en/index.html

2 Xia GL, Liu CB, Cao HL, Bi SL, Zhan MY, Su CA, Nan JH, Qi XQ: Prevalence of hepatitis B and $C$ virus infections in the general Chinese population: results from a nationwide crosssectional seroepidemiologic study of hepatitis $\mathrm{A}, \mathrm{B}, \mathrm{C}, \mathrm{D}$, and $\mathrm{E}$ virus infections in China, 1992. Int Hepatol Commun 1996;5:62-73.

3 Chen YS, Li L, Cui FQ, Xing WG, Wang L, Jia ZY, Zhou MG, Gong XH, Wang FZ, Zheng H, Luo HM, Bi SL, Wang N, Yang WZ, Liang XF: A sero-epidemiological study on hepatitis $\mathrm{C}$ in China. Zhonghua Liu Xing Bing Xue Za Zhi 2011;32:888-891.

4 Qin Q, Smith MK, Wang L, Su Y, Wang L, Guo W, Wang L, Cui Y, Wang N: Hepatitis C virus infection in China: an emerging public health issue. J Viral Hepat 2015;22:238-244.

5 Gao X, Cui Q, Shi X, Su J, Peng Z, Chen X, Lei N, Ding K, Wang L, Yu R, Wang N: Prevalence and trend of hepatitis $\mathrm{C}$ virus infection among blood donors in Chinese mainland: a systematic review and meta-analysis. BMC Infect Dis 2011;11:88-93.

6 Gou H, Pan Y, Ge H, Zheng Y, Wu Y, Zeng J, Yang Z, Pan T, Cun W, Zhou G, Fang G, Zhang J, Zhang K, Zhang R, Sun Y, Xie J, Li J, Wang L: Evaluation of an individual-donation nucleic acid amplification testing algorithm for detecting hepatitis $B$ virus infection in Chinese blood donors. Transfusion 2015; 55:2272-2281.
7 Pham TN, MacParland SA, Mulrooney PM, Cooksley H, Naoumov NV, Michalak TI: Hepatitis $\mathrm{C}$ virus persistence after spontaneous or treatment-induced resolution of hepatitis C. J Virol 2004;78:5867-5874.

8 Castillo I, Pardo M, Bartolomé J, Ortiz-Movilla N, Rodríguez-Iñigo E, de Lucas S, Salas C, Jiménez-Heffernan JA, Pérez-Mota A, Graus J, López-Alcorocho JM, Carreño V: Occult hepatitis $C$ virus infection in patients in whom the etiology of persistently abnormal results of liver-function tests is unknown. J Infect Dis 2004;189:7-14.

9 Pardo M, López-Alcorocho JM, RodríguezIñigo E, Castillo I, Carreño V: Comparative study between occult hepatitis $\mathrm{C}$ virus infection and chronic hepatitis C. J Viral Hepat 2007;14:36-40.

10 Welker MW, Zeuzem S: Occult hepatitis C: how convincing are the current data? Hepatology 2009;49:665-675.

11 Carreno V, Bartolome J, Castillo I, Quiroga JA: New perspectives in occult hepatitis C virus infection. World J Gastroenterol 2012;18: 2887-2894.

12 De Marco L, Gillio-Tos A, Fiano V, Ronco G, Krogh V, Palli D, Panico S, Tumino R, Vineis P, Merletti F, Richiardi L, Sacerdote C: Occult HCV infection: an unexpected finding in a population unselected for hepatic disease. PLoS One 2009;4:e8128.

13 Zhao SM, Jiang TL, Li RQ, Gao FX, Lu L, Zheng HQ, Hu J, Fan YH, Li B, Xiao RQ, Yury $\mathrm{K}: \mathrm{HCV}$ infection in voluntary donors and its influence on recruitment of donors in Chongqing area. Zhongguo Shi Yan Xue Yi Xue Za Zhi 2008;16:676-680.
14 Lu J, Zhou Y, Lin X, Jiang Y, Tian R, Zhang Y, Wu J, Zhang F, Zhang Y, Wang Y, Bi S: General epidemiological parameters of viral hepatitis $\mathrm{A}, \mathrm{B}, \mathrm{C}$, and $\mathrm{E}$ in six regions of China: a cross-sectional study in 2007. PLoS One 2009; 4:e8467.

15 Busch MP: Insights into the epidemiology, natural history and pathogenesis of hepatitis $C$ virus infection from studies of infected donors and blood product recipients. Transfus Clin Biol 2001;8:200-206.

16 Barril G, Castillo I, Arenas MD, et al: Occult hepatitis $\mathrm{C}$ virus infection among hemodialysis patients. J Am Soc Nephrol 2008; 19:22882292.

17 Abdelrahim SS, Khiry RM, Esmail MA, Ragab M, Abdel-Hamid M, Abdelwahab SF: Occult hepatitis $C$ virus infection among Egyptian hemodialysis patients. J Med Virol 2016;88: 1388-1393.

18 Busch MP, Glynn SA, Stramer SL, Orland J, Murphy EL, Wright DJ, Kleinman S; NHLBI Retrovirus Epidemiology Donor Study (REDS) Group: Correlates of hepatitis C virus (HCV) RNA negativity among HCV-seropositive blood donors. Transfusion 2006;46: 469-475.

19 Zaghloul H, El-Sherbiny W: Detection of occult hepatitis $C$ and hepatitis $B$ virus infections from peripheral blood mononuclear cells. Immunol Invest 2010;39:284-291. 
20 Castillo I, Bartolomé J, Quiroga JA, Barril G, Carreno V: Presence of HCV-RNA after ultracentrifugation of serum samples during the follow-up of chronic hepatitis $\mathrm{C}$ patients with a sustained virological response may predict reactivation of hepatitis $\mathrm{C}$ virus infection. Aliment Pharmacol Ther 2009;30:477486.

21 Pham TN, Michalak TI: Occult hepatitis C virus infection and its relevance in clinical practice. J Clin Exp Hepatol 2011;1:185-189.

22 Orland JR, Wright TL, Cooper S: Acute hepatitis C. Hepatology 2002;33:321-327.

23 Bokharaei-Salim F, Keyvani H, Monavari SH, Alavian SM, Madjd Z, Toosi MN, Mohammad Alizadeh AH: Occult hepatitis C virus infection in Iranian patients with cryptogenic liver disease. J Med Virol 2011;83:989-995.
24 Mangus RS, Fridell JA, Kubal CA, Davis JP, Tector AJ: Elevated alanine aminotransferase (ALT) in blood donors: an assessment of the main associated conditions and its relationship to the development of hepatitis C. Rev Inst Med Trop Sao Paulo 1998;40:219224.

25 Gonçales FL Jr, Stucchi RS, Papaiordanou PM, Pavan MH, Gonçales NS, Pinho JR: Determination of alanine aminotransferase in blood donor screening - evidence of its usefulness in the prevention of post-transfusion hepatitis. Clin Lab 2004;50:291-294.

26 Furuta RA, Sakamoto H, Kuroishi A, Yasiui K, Matsukura H, Hirayama F: Metagenomic profiling of the viromes of plasma collected from blood donors with elevated serum alanine aminotransferase levels. Transfusion 2015;55:1889-1899.

27 Attar BM, van Thiel D: A new twist to a chronic HCV infection: occult hepatitis C. Gastroenterol Res Pract 2015;2015:579147.
28 De Marco L, Manzini P, Trevisan M, GillioTos A, Danielle F, Balloco C, Pizzi A, De Filippo E, D'Antico S, Violante B, Valfrè A, Curti F, Merletti F, Richiardi L: Prevalence and follow-up of occult HCV infection in an Italian population free of clinically detectable infectious liver disease. PLoS One 2012;7:e43541.

29 Chen AY, Hoare M, Shankar AN, Allison M, Alexander GJ, Michalak TI: Persistence of hepatitis $\mathrm{C}$ virus traces after spontaneous resolution of hepatitis C. PLoS One 2015;10:e0140312.

30 Quiroga JA, Avellón A, Bartolomé J, Andréu M, Flores E, González MI, González R, Pérez S, Richart LA, Castillo I, Alcover J, Palacios R, Carreño V, Echevarría JM: Detection of hepatitis $\mathrm{C}$ virus (HCV) core-specific antibody suggests occult HCV infection among blood donors. Transfusion 2016;56:1883-1890.

31 Rezaee-Zavareh MS, Ramezani-Binabaj M, Moayed Alavian S: Screening for occult hepatitis $C$ virus infection: does it need special attention? Hepatology 2015;62:321-322. 